\title{
INDEX
}

Acquire new knowledge, 47-48

Adhocracy, 346

Advanced Management Program

(AMP), 195-196

Agents of change, 38-39

AMP. See Advanced Management Program (AMP)

Anglosaxon character, 66

Anthropological model, 81-82

Beginning, transition, 61

Behaviors, 53-54

Building workplace relationships, 48-49

Business culture, 66

Career paths, 108-110

Casablanca, Pedro, 336-337

Catek, Börjesson, Sybila in boss's decision, 249-250

CFO at Scandinavica, 238-239

daily activities, 246-249

first decisions, 244-246

Francisco's opinion, 251

Francisco's point of view, 252-253

new career stage, $241-242$

offer from, 243-244

Ortega, Luis, 239-241

sale of, 251-252

Celebrating bonus sprints, 40-42

Chance to learn, 43-45

Change

agents of, 38-39

sake of, 39

vs. transition, 60-62
Charge effectively, 59-60

Client mentality, 101-102

Command and control style, 40

Communication, 5, 9, 36-37

Communication plan, 52-53

Communication process, 79,80

Company culture, 66

Compensation

pay bands, $110-111$

variable compensation, 111-115

Corporate Commercial School, 196-197

Corporate culture, 78

Corporate responsibilities, 19

Coutin, Philippe, 333-334

Criticisms, 37

Cultural changes, 4

Culture and soft power, 76-77

Culture, concept of, 68

Culture of quality, 67

Decision-executor, 3

Decision-makers, 3, 17-18

Development and training

client mentality, 101-102

priorities, 102-103

short and intense impact,

$$
\text { 103-106 }
$$

Economic efficiency, 80

Effective behaviors, 7-8

Effective decisions, 33

Effective executives, 32

Ending, transition, 60-61

Estévez, Bertrand, 334 
Expectations, 37

Experiences, 37

Extrinsic motivation, 82

Failure to handle the situation, 15

Federation of Spirit Beverages

(FEBE), 331

Financial services company,

$$
\text { 16-17, 16-24 }
$$

Formal appointment, 35

Formal organization and real organization, $70-73$

\section{Google, 65}

Health \& Beauty (H\&B), 157 conflict, 171-173 managing being bypassed, 184-185

managing the team, 165-167 reflections for learning, 182-184

relationship with Nuria Rosal, 167-171

Yolanda's experience, 160-165

Yolanda's position, 173-175

Yolanda's superiors, 175-182

How to Win Friends and Influence People (Carnegie, Dale), 9

HR decision, 19

HR management attract the right talent, 95-96 hiring and recruitment, 93-94 recruitment approach, 94-95

Human organizations and tribes, 69-73

iLEAD, 343

Institutional values, 83 Institution, concept of, 81 Intentions, statements of, 35
Interview

with CEO of Kölner Bank, 202-204

with CEO of logistics company, 27-29

with CEO of software company, 24-25

with president and CEO of financial services company, $16-24$

with sales director multinational telecommunications company, 25-26

Intrinsic motivation, 82

Job banding, 342

Kölner Bank after the holiday, 198-202 conversation with max, 192-193

in Germany, 197-198 Haller, Max, 193-194 interview with CEO, 202-204 Max's departure, 204-205 November 2010, 204 Reiner's career at, 188-191 Reiner's unit, 194-195 transition, 205-206

Laborde, Eric, 329-333

Lack of information, 15

Lack of personal maturity, 15

Landing framework, 155-156

Leader-member exchange

$$
\text { (LMX), 71, } 72
$$

Leadership, 152-153 ability to tolerate conflict, 52 authority and dependency, 62 capacity to work, 52 common pitfalls, 54-57 concentration, 52 confidence, 52 critical self-knowledge, 52 
drive and resilience, 52 empathy with others, 52 persistence, 52 solid ambition, 52 style, 50-52

Lillo, Antonio, 335

Logistics company, 27-29

Maffioli, Massimiliano, 335-336

Manage expectations, 49-50

Management Committee, 321, 334-337

Managing trust, 153-154

Mergers and acquisitions,

122-124

actual merger process, 139

communication, 138

comprehensive, integrative analysis, 131-133

facilitate internal mobility, 133-134

fail, 125-129

full-time interdisciplinary merger, 129-131

identify key people, 138 integration committee, 129-131, 138, 139-143

merger process, $143-146$

organization, 137

real due diligence, 136-137

reality of, 134-136

retention plan, 139

strategy, 137

workforce, 137

Mind map, 45-47

Motivation process, 79, 81

Motivation, theory of, $82-83$

Multinational telecommunications company, 25-26

Networking island, 337

Network of contacts, 4

Neutral zone, transition, 61

New job adjustment, 4-7
Onboarding and integration processes, 96-98

Onboarding processes, 100

Operational goals, 79

Organizational change, $75-76$

Organizational development, 31

Organizational development pyramid, 67

Organizational models, $77-87$

Outstanding producers, 18

People management, 93 compensation, 110-115 development and training, 100-106

evaluation and promotion, 106-110

hiring and recruitment, 93-96

internal communication, 115-117

onboarding and integration processes, 96-100

performance management, 90-93

talent (potential) management, 90-93

Performance management, 90-93

Personal development, 31

Personal effectiveness, 32-33

Pharmacy and Biocosmetics

(P\&B), 157-159

Placement processes, 98-100

Plan the transition, 50

Positive changes, 31

Predecessor matter, 21-22

Priorities, 102-103

PRISA group, 291

PRISA radio, 292

Bolivia, 294-296

Brazil, 296-301

brink of disaster, 305-307

challenges with, 311

digital transformation, 315-318

early years, $292-294$ 
group's finances, 311-312 internationalization and diversification, 312-315 marketing challenge, 307-311 teams, 301-305

Product life cycle, 152

Professional careers, 34

Professional responsibility carries, 34

Profit-and-loss statements, 17-18

Reactive change, 75-76

Ricard, Pernod challenges of, 345-348 competitive strategy of, 338-339

finances of, 339 human resources, 342-344 managers of, 344 surveys, 344-345 values, 339-341

Sake of change, 39 Silicon Valley, 71

Skillfully deal with issues, 8

Skills-based management model, 107-108

Société pour l'Exportation des Grandes Marques (SEGM), 329

Soft power and culture, $76-77$

Software company, 24-25

Start-up, turnaround, accelerated growth, realignment, and sustaining success (STARS) model, 151

Steering Committee, 73-77

Stock market, 17

Strengths productive, $32-33$

Talent identification, 2

Talent (potential) management, 90-93
Teamwork, 24

Theory of leader-member exchange (LMX), 71, 72

Theory of motivation, $82-83$

Top management position, $17-18$

Transcendent motivation, 82

Transformation, 17

Transformational projects, 21

Transformers, 18

Tribes: We Need You to Lead Us

(Godin, Seth), 69

VivaVisión, 265-266

business plan, 274

call from Grupo Luna, 264-265

day-to-day, 275-282

first steps in profession, 259-262

on plane, 282-286

plans and objectives, 280-282

from Sony to Masficción, 262-263

television market in Spain, 266-271

Voice of data, 37-38

West Line, 209-210

career at, 216-219

closer to CEO, 219

getting into management, 223-228

Guillermo, 231-232 memories of Africa, 213-215 Oliva, Guillermo, 212-213 period of mergers, 215-216 transition phase, 220-223 victim of success, 228-230

Yolanda Cruz, 157

See also Health \& Beauty ( $\mathrm{H} \& \mathrm{~B})$ 